\title{
REGENERASI IN VITRO EMPAT VARIETAS KEDELAI (Glycine max [L.] Merr.) MELALUI ORGANOGENESIS MENGGUNAKAN EKSPLAN BIJI YANG DIIMBIBISI DAN DIKECAMBAHKAN
}

\author{
Mohammad Irham Fauzi, Fitri Yelli, Akari Edy \& Setyo Dwi Utomo \\ Jurusan Agroteknologi, Fakultas Pertanian Universitas Lampung \\ Jl.Prof. Soemantri Brodjonegoro, No.1, Bandar Lampung 35145 \\ E-mail: fitrie_yelli@yahoo.com
}

\begin{abstract}
ABSTRAK
Penelitian dilakukan untuk mengetahui pengaruh metode pra-kultur yang efektif dalam meningkatkan efisiensi regenerasi in vitro terhadap eksplan buku kotiledon pada empat varietas kedelai. Penelitian dilaksanakan di Laboratorium Ilmu Tanaman Fakultas Pertanian Universitas Lampung, dimulai dari Maret sampai dengan Mei 2013. Rancangan yang digunakan dalam penelitian ini adalah rancangan acak kelompok. Perlakuan yang diterapkan merupakan kombinasi dari dua faktor yaitu varietas (Detam 1, Detam 2, Burangrang, Panderman) dan metode pra-kultur (kecambah 6 hari dan imbibisi 20 jam) yang merupakan perlakuan terhadap empat varietas benih kedelai tersebut sebelum ditanam pada media inisiasi tunas. Perlakuan disusun secara faktorial (4x2) dengan 5 ulangan. Setiap satuan percobaan terdiri dari empat eksplan buku kotiledon kedelai. Hasil penelitian menunjukkan bahwa rata-rata jumlah tunas adventif per eksplan (RJTAPE) tidak dipengaruhi oleh metode prakultur, varietas dan interaksi antara keduanya. Sedangkan, persentase eksplan yang membentuk tunas adventif (PEMTA) tidak dipengaruhi oleh metode pra-kultur namun dipengaruhi oleh varietas dan interaksi antara kedua faktor tersebut. PEMTA tertinggi didapatkan jika menggunakan varietas Detam 1 melalui perlakuan perkecambahan (70\%) dan varietas Panderman melalui perlakuan imbibisi (50\%). Media pengakaran $1 / 2 \mathrm{MS}$ dan $1 / 2 \mathrm{MS}+\mathrm{NAA} 0,5 \mathrm{mg} \mathrm{l}^{-1}$ memiliki efektifitas yang sama terhadap persentase tunas adventif yang membentuk akar fungsional (PTMAF) pada minggu kedua setelah pengakaran. Dengan demikian, teknik regenerasi secara in vitro melalui organogenesis pada varietas Detam 1 dengan perlakuan perkecambahan dan varietas Panderman dengan perlakuan imbibisi lebih efisien digunakan untuk transformasi genetik kedelai.
\end{abstract}

Kata kunci: Kedelai, imbibisi, kecambah, organogenesis, eksplan biji, varietas

\section{PENDAHULUAN}

Kebutuhan kedelai setiap tahun mencapai 2 juta ton, sedangkan produksi kedelai dalam negeri hanya 0,8 juta ton per tahun sehingga diperlukan impor sebanyak 1,2 juta ton per tahun yang berdampak menghabiskan devisa negara sekitar Rp 3 triliun per tahun. Selain itu, impor bungkil kedelai telah mencapai kurang lebih 1,3 juta ton per tahun yang menghabiskan devisa negara sekitar Rp 2 triliun per tahun (Alimoeso, 2006). Permintaan kedelai meningkat sebesar $5,8 \%$ per tahun (Marveldani et al., 2007 a). Namun produksi kedelai secara nasional tiap tahun terus menurun. Menurut Badan Pusat Statistik (2012), pada tahun 2009 luas panen kedelai sebesar 722.791 ha dengan produksi sebesar 974.512 ton. Pada tahun 2010, luas panen tersebut menjadi 660.823 ha dengan produksi 907.031 ton. Selanjutnya tahun 2011 luas panen 622.254 ha dan produksi menjadi 851.286 ton. Pada tahun 2012 luas panen menjadi 567.871 ha dengan produksi 851.647 ton. Penurunan produksi tersebut terjadi di Jawa sebesar
59,09 ribu ton, sedangkan di luar pulau jawa mengalami peningkatan sebesar 3,35 ribu ton. Menurut Hosen dan Atman (2008), proyeksi permintaan kedelai tahun 2018 sebesar 6,11 juta ton sehingga tanpa kebijakan khusus sampai tahun 2018 kebutuhan kedelai nasional tetap akan bergantung pada impor.

Kebijakan intensifikasi dan ekstensifikasi perlu dilakukan untuk meningkatkan produksi kedelai dalam negeri. Intensifikasi dapat dilakukan dengan menggunakan varietas unggul yang dapat dihasilkan melalui teknik rekayasa genetika atau transformasi genetik (Marveldani et al., 2007 b). Menurut Clemente et al. (2000), perakitan tanaman transgenik dapat diarahkan untuk memperoleh kultivar (varietas budidaya) tanaman yang memiliki produksi tinggi, nutrisi dan penampilan berkualitas tinggi, maupun resisten terhadap hama, penyakit, dan cekaman lingkungan. Tanaman kedelai toleran herbisida merupakan salah satu contoh tanaman rekayasa genetika. Menurut Utomo (2012), varietas merupakan sekelompok tanaman dalam satu spesies yang secara genetik memiliki kriteria DUS yaitu 
distinct (berbeda), uniform (seragam), dan stable (stabil). Varietas budidaya (kultivar) yang memiliki sifat unggul bernilai ekonomi disebut varietas unggul. Jenis varietas unggul terdiri dari varietas galur murni (inbrida), hibrida, komposit, sintetik, multi galur, dan klon. Berbagai jenis varietas tersebut dapat dirakit menggunakan teknik pemuliaan tradisional maupun modern (bioteknologi) melalui transformasi genetik.

Keberhasilan transformasi genetik untuk memperoleh tanaman transgenik sangat ditentukan oleh teknik regenerasi in vitro. Regenerasi in vitro pada dasarnya mengacu pada teori totipotensi dari Schleiden dan Schwan. Menurut teori tersebut setiap sel hidup mempunyai kemampuan untuk bereproduksi, membentuk organ, dan berkembang menjadi individu baru yang sempurna/utuh jika ditumbuhkan pada media dan lingkungan yang sesuai. Teori ini dijadikan dasar dalam perbanyakan tanaman melalui manipulasi sel atau jaringan tanaman menjadi organ atau tanaman utuh secara in vitro atau kultur jaringan (Pardal, 2002). Menurut Utomo (2005), regenerasi in vitro atau kultur jaringan berfungsi untuk meregenerasikan tanaman transgenik dari sel atau jaringan transgenik.

Perbanyakan tanaman melalui kultur jaringan dapat ditempuh melalui dua jalur, yaitu organogenesis dan embriogenesis somatik (Lestari, 2011). Menurut Wattimena et al. (1992), pada hakikatnya organogenesis tanaman secara in vitro dikendalikan oleh keseimbangan dan interaksi hormon yang berada dalam eksplan (endogen) dengan hormon yang diserap dari media tumbuh (eksogen). Bentuk keseimbangan yang terjadi akan menentukan arah dan bentuk pertumbuhan, salah satunya pembentukan shootlet (tunas). Tunas yang dibentuk berdasarkan kompetensi (kemampuan) eksplan sangat menentukan keberhasilan regenerasi in vitro melalui organogenesis. Kompetensi eksplan dipengaruhi oleh interaksi dan keseimbangan hormon auksin dan sitokinin. Perlakuan imbibisi dan perkecambahan benih sebagai sumber eksplan diharapkan akan memperbaiki kompetensi eksplan untuk tujuan pembentukan tunas. Menurut Sumarno dan Widiyati (1985), pada proses imbibisi, air masuk kedalam benih menyebabkan pengembangan embrio dan endosperm sehingga kulit benih menjadi pecah dan proses-proses fisiologi di dalam benih menjadi aktif. Air melakukan fungsinya untuk mengaktifkan kinerja dan perubahan hormon endogen didalam benih untuk proses perkecambahan. Selanjutnya, perubahan tersebut akan mempengaruhi kompetensi eksplan untuk beregenerasi membentuk tunas. Oleh karena itu, penelitian ini dilakukan untuk mengetahui metode pra-kultur berupa perlakuan imbibisi dan perkecambahan pada benih kedelai yang efektif dalam meningkatkan efisiensi regenerasi in vitro melalui organogenesis.

\section{BAHAN DAN METODE}

Perlakuan disusun secara factorial $(4 \times 2)$ dalam rancangan acak kelompok (RAK). Faktor pertama yaitu varietas (Detam 1, Detam 2, Burangrang dan Panderman) dan faktor kedua yaitu metode pra-kultur (imbibisi 20 jam dan kecambah 6 hari). Metode prakultur adalah perlakuan yang diberikan terhadap benih kedelai yang digunakan sebelum ditanam pada media inisiasi tunas. Perlakuan disusun secara faktorial $(4 \times 2)$ dengan 5 ulangan. Setiap satuan percobaan terdiri dari empat eksplan buku kotiledon kedelai. Setelah metode pra-kultur dilakukan, selanjutnya eksplan buku kotiledon ditanam pada media inisiasi tunas yaitu MS + BA 0,75 $\mathrm{mg} \mathrm{l}^{-1}$. Homogenitas ragam data antar perlakuan diuji dengan menggunakan uji Bartlett dan uji lanjut dengan uji beda nyata terkecil (BNT) pada taraf $5 \%$.

Tahap penelitian diawali dengan sterilisasi benih di dalam desikator selama $2 \times 24$ jam. Prosedur sterilisasi yaitu dengan menaruh selapis benih kedelai dari masing-masing varietas didalam cawan petri terbuka kemudian ditempatkan mengelilingi gelas piala yang sudah berisi campuran $3 \mathrm{ml} \mathrm{HCL}$ dan $100 \mathrm{ml}$ Bayclin didalam desikator. Pada metode pra-kultur melalui perlakuan perkecambahan selama 6 hari, benih kedelai dari empat varietas yang telah disterilisasi kemudian ditanam ke dalam media MS0 dan diinkubasi pada suhu $24 \pm 2^{\circ} \mathrm{C}$ dalam kondisi terang selama 16 jam dan gelap selama 8 jam. Sedangkan pada perlakuan imbibisi 20 jam, benih kedelai yang telah disterilisasi lalu dimasukkan ke dalam erlenmeyer ukuran $100 \mathrm{ml}$ yang berisi air steril 40-50 ml.

Proses inisiasi tunas pada perlakuan kecambah 6 hari dan imbibisi 20 jam, dimulai dengan memisahkan kotiledon dari hipokotil dengan cara memotong hipokotil 3-5 mm di bawah buku kotiledon. Dua buku kotiledon dipisahkan dengan cara membelah vertikal sepanjang hipokotil menggunakan pisau skapel bernomor 15. Pucuk poros embrio di atas buku kotiledon dibuang, kemudian dibuat 5 sampai 7 kali goresan sejajar dengan poros embrio pada buku kotiledon. Posisi eksplan pada media $1 / 2 \mathrm{MS}+\mathrm{BA} 0,75 \mathrm{mg} \mathrm{l}^{-1}$ condong dengan sudut $120^{\circ}$, permukaan adaksial menghadap ke atas dan bagian yang dicacah dibenamkan dalam media. Eksplan tersebut dikulturkan selama dua minggu pada suhu $24 \pm 2{ }^{\circ} \mathrm{C}$ dalam kondisi terang selama 16 jam dan gelap selama 8 jam. Pengamatan dilakukan terhadap tunas adventif yang telah mempunyai lebih dari tiga daun baik dari perlakuan imbibisi maupun perkecambahan. Tunas 
tersebut selanjutnya diakarkan pada dua jenis media pengakaran yaitu $1 / 2$ MS dan $1 / 2 \mathrm{MS}+\mathrm{NAA} 0,5 \mathrm{mg} \mathrm{l}^{-1}$. Variabel yang diamati untuk mengetahui efisiensi regenerasi in vitro empat varietas kedelai tersebut melalui metode organogenesis antara lain:

1) Rata-rata jumlah tunas adventif per eksplan (RJTAPE) pada 40 hari setelah tanam.

$$
\text { RJTAPE }=\frac{\text { Jumlah tuasadventifpereksplan }}{\text { Jumlaheksplanyangmembentukunas }}
$$

2) Persentase eksplan yang membentuk tunas adventif (PEMTA) pada 40 hari setelah tanam.

$$
\text { PEMTA }=\frac{\text { Jumlaheksplan yang membentuktunasadventif per satuanpercobaan }}{\text { Jumlaheksplanyang ditanamper satuanpercobaan }} x 100 \%
$$

3) Persentase tunas adventif yang membentuk akar fungsional (PTMAF) pada 2 minggu setelah pengakaran.

$$
\text { PTMAF }=\frac{\text { Jumlah turas adventif yangmembentukakarfungsional }}{\text { Jmlah tuns adventif yangditanamdi mediapengakaran }} x 100 \%
$$

\section{HASIL DAN PEMBAHASAN}

Berdasarkan Gambar 1, varietas Detam 1 dengan perlakuan kecambah menunjukkan persentase eksplan yang membentuk tunas adventif lebih tinggi dibanding dengan perlakuan imbibisi. Pada varietas Detam 2 tidak terdapat perbedaan persentase eksplan yang membentuk tunas adventif antara perlakuan imbibisi dan kecambah . Pada varietas Burangrang dan varietas Panderman dengan perlakuan imbibisi memiliki persentase eksplan yang membentuk tunas adventif lebih tinggi daripada dengan perlakuan kecambah.
Pada penelitian ini, persentase eksplan yang membentuk tunas adventif tertinggi dari perlakuan kecambah adalah varietas Detam $1(70 \%)$ dan dari perlakuan imbibisi adalah varietas Panderman (50\%). Persentase eksplan yang membentuk tunas adventif tertinggi tersebut lebih rendah daripada persentase eksplan yang membentuk tunas adventif tertinggi dari perlakuan kecambah dan imbibisi pada penelitian Safitri (2013). Hasil penelitian Safitri (2013) menunjukkan bahwa persentase eksplan yang membentuk tunas adventif tertinggi dari perlakuan imbibisi dimiliki oleh varietas Anjasmoro $(87 \%)$ dan perlakuan kecambah

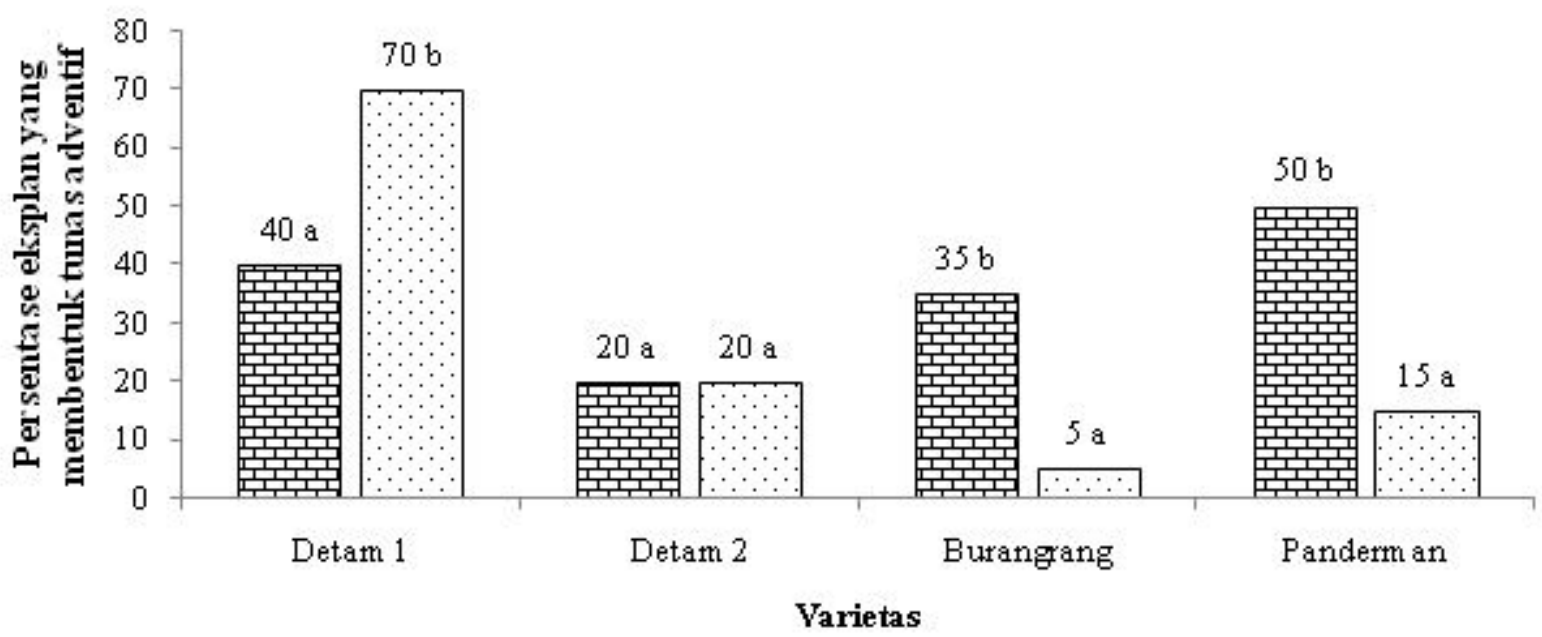

Gambar 1. Pengaruh metode pra-kultur melalui imbibisi dan kecambah pada setiap varietas terhadap persentase eksplan yang membentuk tunas adventif. Angka yang diikuti huruf yang sama pada setiap varietas tidak berbeda nyataberdasarkan uji BNT (BNT 5\% = 28,51). $\square=$ imbibisi, $\square=$ kecambah. 
(87 \%).Dengan demikian, perbedaan varietas akan mempengaruhi respon yang berbeda terhadap pembentukan tunas adventif. Setiap varietas dengan perlakuan imbibisi dan kecambah menunjukkan respon yang berbeda terhadap efisiensi regenerasi in vitro. Perbedaan respon varietas tersebut dikuatkan oleh Wattimena et al. (1992) bahwa antarvarietas yang memiliki sifat dekat memiliki kebutuhan akan lingkungan dan media yang berbeda. Selain itu didukung juga oleh Pierik (1987), yang menyatakan bahwa masing-masing jenis eksplan dan genotip memiliki respon pertumbuhan in vitro yang berbeda-beda walaupun ditumbuhkan pada media dan kondisi lingkungan tumbuh yang sama.

Pada Tabel 1, persentase tunas adventif yang membentuk akar fungsional (PTMAF) dari perlakuan imbibisi di media $1 / 2$ MS dengan media $1 / 2 \mathrm{MS}+\mathrm{NAA}$
$0,5 \mathrm{mg} \mathrm{l}^{-1}$ maupun antara PTMAF dari perlakuan kecambah di media $1 / 2$ MS dengan media $1 / 2 \mathrm{MS}+\mathrm{NAA}$ $0,5 \mathrm{mg} \mathrm{l}^{-1}$ menunjukkan efektifitas yang sama dalam pembentukan akar fungsional. Berdasarkan Gambar 2, tunas adventif yang ditanam di media $1 / 2$ MS dan $1 / 2$ MS + NAA $0,5 \mathrm{mg} \mathrm{l}^{-1}$ memiliki perbedaan berdasarkan karakteristik akar fungsional. Tunas adventif yang terbentuk pada media pengakaran $1 / 2$ MS memiliki akar fungsional yang memanjang, berukuran kecil, barwarna putih dari pangkal sampai ke ujung dan berjumlah sedikit. Sedangkan pada media pengakaran $1 / 2$ MS + NAA 0,5 $\mathrm{mg} \mathrm{l}^{-1}$ memiliki akar yang pendek, berukuran lebih besar, berwarna coklat dari pangkal sampai ke ujung, dan berjumlah lebih banyak.

Level hormon eksogen dari golongan auksin dapat memberikan pengaruh yang lebih efektif terhadap

Tabel 1. Persentase tunas adventif yang membentuk akar fungsional (PTMAF) dari dua jenis media pengakaran dan metode pra-kultur pada 2 msp (minggu setelah pengakaran).

\begin{tabular}{|c|c|c|c|c|c|c|c|c|c|c|c|c|}
\hline \multirow{4}{*}{ Varietas } & \multicolumn{12}{|c|}{ Media pengakaran } \\
\hline & \multicolumn{6}{|c|}{ Media 1/2 MS } & \multicolumn{6}{|c|}{ Media $1 / 2 \mathrm{MS}+$ NAA $0,5 \mathrm{mg} \mathrm{l}^{-1}$} \\
\hline & \multicolumn{3}{|c|}{ Imbibisi } & \multicolumn{3}{|c|}{ Kecambah } & \multicolumn{3}{|c|}{ Imbibisi } & \multicolumn{3}{|c|}{ Kecambah } \\
\hline & $\mathbf{A}$ & B & $\mathbf{C}$ & $\mathbf{A}$ & B & $\mathbf{C}$ & $\mathbf{A}$ & B & $\mathbf{C}$ & $\mathbf{A}$ & B & $\mathbf{C}$ \\
\hline Detam 1 & 8 & 8 & 100 & 10 & 8 & 80 & 9 & 9 & 100 & 11 & 11 & 100 \\
\hline Detam 2 & 6 & 4 & 67 & 4 & 4 & 100 & 4 & 3 & 75 & 7 & 7 & 100 \\
\hline Burangrang & 9 & 8 & 88 & 1 & 1 & 100 & 4 & 4 & 100 & 1 & 1 & 100 \\
\hline Panderman & 15 & 15 & 100 & 3 & 3 & 100 & 11 & 10 & 90 & 4 & 4 & 100 \\
\hline Rata-rata & \multicolumn{3}{|c|}{88.75} & \multicolumn{3}{|c|}{95} & \multicolumn{3}{|c|}{91.25} & \multicolumn{3}{|c|}{100} \\
\hline
\end{tabular}

Keterangan : Uji-t pada taraf signifikan $5 \%(3,18), \mathrm{A}=$ jumlah tunas adventif yang ditanam pada media pengakaran, $\mathrm{B}=$ jumlah tunas adventif yang membentuk akar fungsional,dan $\mathrm{C}=$ persentase tunas adventif yang membentuk akar fungsional.
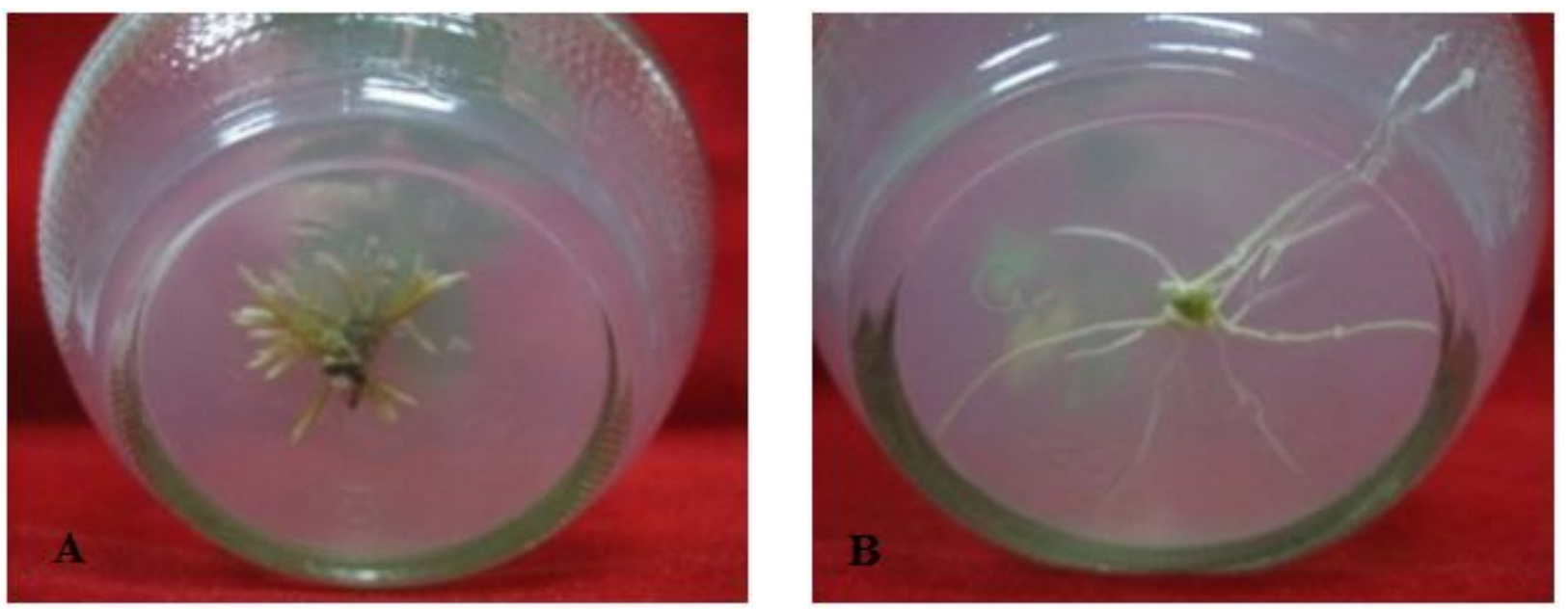

Gambar 2. Akar fungsional varietas Panderman umur 2 msp dengan perlakuan imbibisi, (A) Akar fungsional di media $1 / 2 \mathrm{MS}$, (B) Akar fungsional di media $1 / 2 \mathrm{MS}+\mathrm{NAA} 0,5 \mathrm{mg}^{-1}$ 
pembentukan akar fungsional jika mampu melebihi level hormon sitokinin endogen. Hal tersebut didukung oleh pernyataan Wattimena et al. (1992), bahwa pembentukan akar secara in vitro hanya memerlukan auksin tanpa sitokinin atau sitokinin dalam konsentrasi yang rendah sekali. Pada penelitian ini, kemungkinan level hormon auksin eksogen untuk media pengakaran (menggunakan NAA) masih dibawah level hormon sitokinin endogen dari tunas adventif. Dengan demikian, penggunaan media pengakaran dengan menggunakan NAA yang seharusnya dapat lebih efektif daripada tanpa NAA dalam pembentukan akar fungsional, namun ternyata dalam penelitian ini NAA dengan konsentrasi $0,5 \mathrm{mg} \mathrm{l}^{-1}$ diduga belum ideal dalam pembentukan akar fungsional sehingga efektifitasnya sama dengan media $1 / 2$ MS.

Penggunaan media $1 / 2$ MS pada penelitian ini terbukti efektif mampu membentuk akar fungsional yang lebih panjang walaupun berukuran kecil, dan berjumlah sedikit dibanding akar fungsional pada media $1 / 2 \mathrm{MS}+$ NAA 0,5 $\mathrm{mg} \mathrm{l}^{-1}$. Menurut Wattimena et al. (1992), pada tanaman terdapat auksin endogen yang cukup untuk membentuk akar sehingga akar akan tetap terbentuk walau tanpa penambahan auksin. Hasil penelitian ini didukung oleh hasil penelitian Sofia (2007) bahwa jumlah akar terbanyak dijumpai pada perlakuan 0 ppm BAP (1,424 buah). Sedangkan pengaruh CCC terhadap jumlah akar yang terbentuk menunjukkan bahwa jumlah akar terbanyak dijumpai pada perlakuan $0 \mathrm{ppm}$ CCC (1,383 buah). Jumlah akar terbanyak dijumpai pada kombinasi perlakuan 0 ppm BAP dan 0 ppm CCC $(1,858$ buah).

\section{KESIMPULAN}

Metode pra-kultur, varietas dan interaksi antara metode pra-kultur dengan varietas tidak mempengaruhi rata-rata jumlah tunas adventif per eksplan. Persentase eksplan yang membentuk tunas adventif lebih efektif diperoleh jika menggunakan varietas Detam 1 melalui perlakuan perkecambahan (70\%), varietas Panderman melalui perlakuan imbibisi (50\%), varietas Burangrang melalui perlakuan imbibisi (35\%) dan varietas Detam 2 baik melalui perlakuan imbibisi maupaun perkecambahan (20\%). Media pengakaran $1 / 2$ MS dan $1 / 2$ MS + NAA $0,5 \mathrm{mg} \mathrm{l}^{-1}$ memiliki efektifitas yang sama terhadap persentase tunas adventif yang membentuk akar fungsional pada minggu kedua setelah pengakaran. Dengan demikian, teknik regenerasi secara in vitro melalui organogenesis pada varietas Detam 1 dengan perlakuan perkecambahan dan varietas Panderman dengan perlakuan imbibisi lebih efisien digunakan untuk transformasi genetik kedelai.

\section{DAFTAR PUSTAKA}

Alimoeso, S. 2006. Deptan RI Canangkan Program Bangkit Kedelai. (www.jabar.go.id).

Diunduh 25 Februari 2013.

Badan Pusat Statistik. 2012. Produksi Padi, Jagung, Dan Kedelai Angka Tetap 2011 dan Angka Ramalan I 2012 (www.bps.go.id/brs_file/aram_2jul12. pdf). Berita Resmi Statistik No. 43/07/Th. XV, 2 Juli 2012. Diakses 2 Februari 2013.

Clemente, T., B. J. La Valle, A. R. Howe, D. C. Ward, R. J. Rozman, P. E. Hunter, D. L. Broyles, D. S. Kasten, and M. A. Hinchee. 2000. Progeny Analysis of Glyphosate Selected Transgenic Soybeans derived from Agrobacterium mediated transformation. Crop Sci. (40): 797-803.

Hosen, Nasrul dan Atman. 2008. Dukungan Teknologi Dan Kebijakan Dalam Pengembangan Tanaman Kedelai Di Sumatera Barat. Jurnal Ilmiah Tambua (VII), No. 3, September-Desember 2008. Balai Pengkajian Teknologi Pertanian (BPTP) sumatera Barat. 347-359 hlm.

Lestari, E.G. 2011. Peranan Zat Pengatur Tumbuh dalam Perbanyakan Tanaman melalui Kultur Jaringan. Jurnal AgroBiogen. (VII), No. 1. Hal: 63-68.

Marveldani, Maimun B., dan Setyo D.U. 2007 a. Regenerasi In Vitro Kedelai Melalui Organogenesis pada Tiga Konsentrasi Benziladenin. Jurnal Penelitian dan Informasi Pertanian. "Agrin” (XI), No. 2, Oktober 2007. Hal : 85.

Marveldani, Maimun B., Kukuh S., dan Setyo, D.U. 2007 b. Pengembangan Kedelai Transgenik yang Toleran Herbisida Amonium-Glufosinat dengan Agrobacterium. Jurnal Akta Agrosia (X), No. 1, Januari-Juni 2007. Hal: 54.

Pardal, Saptowo J. 2002. Perkembangan Penelitian Regenerasi dan Transformasi Pada Tanaman Kedelai. Balai Penelitian Bioteknologi dan Sumberdaya Genetik Pertanian. Buletin Agrobio (V), No. 2. Hal: 37-44.

Pierik, R.L.M. 1987. In vitro culture of higher plants. Martinus Nijhoff Publisher, Dordrecht, Boston, Lancaster. 344 pp. 
Wattimena, G.A., Livy Winata, G., Nurhayati, A.M., Endang S., Ni Made A.W., dan Andri, E. 1992. Bioteknologi tanaman. Departemen Pendidikan dan Kebudayaan, Direktorat Jendral Pendidikan Tinggi, PAU Bioteknologi IPB. $71 \mathrm{hlm}$.

Safitri, Y. 2013. Pengaruh Perlakuan Pra-Kultur Terhadap Efisiensi Regenerasi In Vitro Lima Varietas Kedelai. Skripsi. Fakultas Pertanian Universitas Lampung. Bandar Lampung. Hal: 37-38.

Sofia, Diana. 2007. Pengaruh Berbagai Konsentrasi BAP dan Cycocel (CCC) Terhadap Pertumbuhan Embrio Kedelai Secara In Vitro. Karya tulis. Fakultas Pertanian Universitas Sumatera Utara. $24 \mathrm{hlm}$.
Sumarno dan Widiyati. 1985. Produksi dan Teknologi Benih Kedelai. Balitan Bogor. Bogor. Hal: 407428.

Utomo, S.D. 2005. Efisiensi Regenerasi in Vitro Enam Varietas Kedelai Melalui Organogenesis. Agrista 9 (1): 83-92.

Utomo, S.D. 2012. Pemuliaan Tanaman Menggunakan Rekayasa Genetik. Lembaga Penelitian Universitas Lampung. Bandar Lampung. Hal : 2. 